Ekspansi: Jurnal Ekonomi, Keuangan, Perbankan dan Akuntansi

ISSN (Online): 2580-7668 ISSN (Print): 2085-5230

Vol. 11, No. 1 (Mei 2019), Hal. 1 - 11

\title{
ANALISA PENGARUH PERTUMBUHAN KREDIT, JENIS KREDIT, TINGKAT BUNGA PINJAMAN BANK DAN INFLASI TERHADAP KREDIT BERMASALAH
}

\author{
Arfan Rachmadias Saputro ${ }^{1}$, Susi Sarumpaet ${ }^{2}$, Tri Joko Prasetyo ${ }^{3}$ \\ 1,2,3 Universitas Lampung, Bandar Lampung, Indonesia \\ Email Korespondensi: a.rachmadias@gmail.com
}

\begin{abstract}
This research was conducted to analyze the effect of loan growth, loan type, interest and inflation on non-performing loan. Samples were focused on Indonesian commercial banks. Multiple regression linear analysis was used, whereas the samples were obtained using purposive sampling method. Total sample consists of 82 commercial banks with financial statements for the year of 2013 to 2017. Result shows that each variable; loan growth, loan type and interest have a positive effect on nonperforming loan. On the other hand, inflation has a negative effect.
\end{abstract}

Keywords: Loan Growth, Loan Type, Interest, Inflation, Non-Performing Loan.

Abstrak: Penelitian ini dilakukan untuk menganalisa pengaruh dari pertumbuhan kredit, jenis kredit, tingkat bunga pinjaman bank dan inflasi terhadap kredit bermasalah. Sampel dikonsentrasikan pada bank umum yang ada di Indonesia. Metode analisa yang digunakan adalah regresi linier berganda dengan teknik pengambilam sampel menggunakan purposive sampling. Total sampel yang diperoleh terdiri dari 82 bank umum dengan periode laporan keuangan selama tahun 2013 sampai dengan tahun 2017. Hasil penelitian menunjukkan bahwa masing-masing variabel; pertumbuhan kredit, jenis kredit dan tingkat bunga pinjaman bank memberikan pengaruh positif terhadap kredit bermasalah, sedangkan inflasi berpengaruh negatif terhadap kredit bermasalah.

Kata Kunci: Pertumbuhan Kredit, Jenis Kredit, Tingkat Bunga Pinjaman Bank, Inflasi, Kredit Bermasalah.

DOI: 10.35313/ekspansi.v11i1.1325

Riwayat Artikel:

Diterima: 12 - $10-2018$

Direvisi: $25-11-2018$

Disetujui: $1-12-2018$ 


\section{PENDAHULUAN}

Pertumbuhan ekonomi dunia terus mengalami pelambatan, pada tahun 2014 sebesar 3,4\% kemudian turun menjadi 3,2\% pada tahun 2015 dan pada tahun 2016 kembali turun menjadi 3,1\% (LPI, 2016). Faktor-faktor yang mempengaruhi pelambatan ekonomi dunia tersebut antara lain; 1) Pertumbuhan ekonomi yang menurun di Amerika Serikat akibat kinerja sektor minyak dan pertambangan yang masih turun. 2) Perlambatan investasi di Eropa pasca referendum Brexit pada akhir Juni 2016. 3) Penurunan pada hampir seluruh komponen PDB (konsumsi, investasi, dan ekspor) di Jepang. 4) Strategi economic rebalancing yang dilakukan oleh pemerintah Tiongkok dalam merespons perekonomian global yang belum kuat (LPI, 2016). Hal tersebut dapat memberikan dampak yang signifikan bagi perekonomian Indonesia dimana kondisi ekonomi tersebut sangat berpengaruh pada sektor perbankan dimana rentan terjadinya peningkatan kredit bermasalah. Kondisi kredit bermasalah di Indonesia apabila dibandingkan dengan negara ASEAN lainnya berada pada angka yang cukup tinggi, dimana pada tahun 2016 gross NPL di Indonesia adalah sebesar 2,9\% sementara di Filipina, Malaysia dan Singapura masing-masing adalah sebesar $1,7 \%, 1,6 \%$ dan $1,2 \%$ (data.worldbank.org, 2017).

Kredit bermasalah yang tinggi, dapat menimbulkan risiko turunnya kinerja sektor perbankan. Hal tersebut terkait dengan tingginya Cadangan Kerugian Penurunan Nilai (CKPN) yang harus dicadangkan oleh perbankan apabila terdapat kredit bermasalah yang terus membengkak. Risiko tersebut harus ditekan serendah mungkin sehingga NPL dapat diminimalisir. Langkah-langkah strategis tahun 2017 yang telah ditetapkan oleh beberapa bank seperti Bank Mandiri untuk menargetkan pertumbuhan NPL menjadi sebesar 3,5\% (ekonomi.kompas.com, 2017) dan Bank BTN menargetkan pertumbuhan NPL menjadi maksimal sebesar 3\% (infobanknews.com, 2017).

Disisi lain, sebagai sebuah badan usaha, bank terus dituntut untuk dapat menyalurkan kredit sesuai dengan target yang telah ditetapkan oleh masing-masing bank. Hal tersebut terkait dengan misi bank sebagai Lembaga intermediasi antara unit surplus dan unit defisit. Lebih lanjut, merupakan kewajiban moral perbankan untuk menyalurkan kredit, dimana sumber utama dana bank berasal dari masyarakat, sehingga sewajarnya bila bank memiliki kewajiban untuk kembali menyalurkannya kepada masyarakat dalam bentuk kredit (Firmansyah, 2014).

Ditinjau dari akar permasalahan, terdapat dua faktor penyebab terjadinya kredit bermasalah yaitu faktor internal dan faktor eksternal. Faktor internal antara lain berasal dari pertumbuhan kredit, dimana ketika bank melakukan pertumbuhan kredit yang tinggi dalam waktu yang cepat, bank cenderung untuk menurunkan standar dalam memilih nasabahnya (Keeton, 1999). Sementara dari jenis kredit yang disalurkan berdasarkan penggunaannya, kredit dibagi menjadi dua jenis yakni; 1) kredit konsumtif dimana sumber pembayarannya umumnya diperoleh dari gaji atau pendapatan lain nasabah, bukan berasal dari objek yang dibiayainya dan 2) kredit komersial yang sumber pembayarannya berasal dari usaha yang dibiayainya (Ikatan Bankir Indonesia dan Lembaga Sertifikasi Profesi Perbankan, 2013), dengan demikian kepastian pembayaran akan lebih terjaga pada kredit konsumtif. Faktor internal 
lainnya adalah tingkat bunga pinjaman bank, dimana tingkat bunga pinjaman bank atau biasa dikenal dengan suku bunga dasar kredit (SBDK) yang merupakan suku bunga terendah atau suku bunga dasar bank dalam menentukan suku bunga kredit yang dikenakan kepada nasabah (SE No.15/1/DPNP, 2013), sehingga berpengaruh terhadap kemampuan membayar nasabah. Sedangkan faktor eksternal dapat berasal dari inflasi, dimana Inflasi dapat didefinisikan sebagai peningkatan pada harga secara umum dan secara berkelanjutan (bi.go.id, 2017), dan hal tersebut dapat memicu turunnya daya beli masyarakat.

\section{TINJAUAN PUSTAKA}

Teori sinyal dapat diartikan bahwa perusahaan (manajemen) memiliki informasi kualitatif yang berlebih dibandingkan dengan investor dan perusahaan (manajemen) tersebut menggunakan sarana seperti laporan keuangan untuk menyampaikan kondisi perusahaannya, kemudian apabila investor tidak mampu untuk menangkap sinyal tersebut, maka mereka tidak akan bisa memperoleh manfaat yang maksimal (Gumanti, 2009). Pada penelitian berikut, tingkat kredit bermasalah yang menggambarkan kesehatan suatu perbankan dapat menjadi sinyal bagi konsumen dan investor.

Dalam dunia perbankan dapat terjadi asimetri informasi antara pihak pemberi pinjaman (bank) dan peminjam (nasabah), dimana peminjam memiliki informasi lebih dibandingkan dengan bank terkait sumber pendapatannya. Dengan demikian hubungan dengan nasabah (peminjam) dalam proses pemberian kredit muncul akibat adanya asimetri informasi (Sharpe, 1990), kondisi ini dilakukan oleh bank untuk mengetahui kondisi dari peminjam yang sesungguhnya. Pada penelitian berikut, asimetri informasi dapat dijumpai pada jenis kredit yang diberikan dan kaitannya terhadap kelancaran pembayarannya. Pada kredit konsumtif sumber pembayarannya umumnya diperoleh dari gaji atau pendapatan lain nasabah, bukan berasal dari objek yang dibiayainya sedangkan pada kredit komersial sumber pembayarannya berasal dari usaha yang dibiayainya (Ikatan Bankir Indonesia dan Lembaga Sertifikasi Profesi Perbankan, 2013). Berdasarkan hal tersebut dapat disimpulkan bahwa asimetri informasi akan lebih cenderung terjadi pada kredit komersial dimana para pelaku usaha memiliki informasi lebih atas pendapatan usahanya dibandingkan dengan bank sebagai pemberi kredit.

Bank, sesuai Undang-undang No. 8 tahun 1992 tentang perbankan yang telah diubah menjadi Undang-undang No. 10 tahun 1998 merupakan badan usaha yang bertujuan untuk mengumpulkan dana dari masyarakat dalam bentuk simpanan kemudian menyalurkannya kembali pada masyarakat dalam bentuk kredit atau dalam bentuk lainnya dengan tujuan untuk meningkatkan taraf hidup rakyat banyak. Dalam menjalankan usahanya, perbankan tentu wajib memperhatikan risiko yang mungkin terjadi. Risiko merupakan sebuah akibat dari suatu peristiwa yang berpotensi menimbulkan kerugian (Ikatan Bankir Indonesia dan Lembaga Sertifikasi Profesi Perbankan, 2013). Maka dari itu, untuk meminimalisir kerugian tersebut bank menerapkan manajemen risiko. Menurut Ikatan Bankir Indonesia dan Lembaga Sertifikasi Profesi Perbankan (2013), manajemen risiko merupakan sebuah rangkaian 
metode dan prosedur yang digunakan untuk mengidentifikasi, mengukur, memantau serta mengendalikan risiko yang timbul dari seluruh kegiatan usaha bank.

Risiko kredit merupakan risiko yang timbul akibat dari kegagalan debitur dalam memenuhi kewajibannya kepada bank (Ikatan Bankir Indonesia dan Lembaga Sertifikasi Profesi Perbankan, 2013). Dalam mengantisipasi risiko kredit secara dini, bank menetapkan kolektibilitas bagi setiap kredit yang telah diberikan kedalam lima kategori yakni; Kolektibilitas 1 (Lancar), Kolektibilitas 2 (Dalam Perhatian Khusus), Kolektibilitas 3 (Kurang Lancar), Kolektibilitas 4 (Diragukan) dan Kolektibilitas 5 (Macet) (Ikatan Bankir Indonesia dan Lembaga Sertifikasi Profesi Perbankan, 2013). Selain itu, dalam pencatatan keuangannya, bank juga diwajibkan untuk mencadangkan nilai sebagai penyisihan penurunan nilai aset atas aset produktif dan aset non produktifnya. Cadangan tersebut dicatat berdasarkan kualitas kredit yang telah ditetapkan oleh bank tersebut. Dalam PBI No. 14/15/PBI/2012 tahun 2012, disampaikan bahwa kualitas kredit ditentukan atas dasar penilaian pada kondisi usaha kedepan, kinerja dan kemampuan membayar debitur.

Dalam menyalurkan kreditnya, tentu besar harapan bank bahwa kredit tersebut dapat dilakukan pembayarannya sesuai dengan skema yang telah disepakati dengan nasabah. Namun pada kenyataannya tidak semua kredit yang disalurkan dapat terbayarkan sesuai dengan perjanjian, hal inilah yang menimbulkan kredit bermasalah/wanprestasi. Berdasarkan PBI No. 14/15/PBI/2012 tahun 2012 dijelaskan bahwa debitur dinyatakan wanprestasi jika satu dari ketiga kriteria berikut terpenuhi:

a. Terdapat tunggakan selama 90 (sembilan puluh) hari atas pokok dan/atau bunga dan/atau tagihan lainnya meskipun Aset Produktif belum jatuh tempo;

b. Pada saat Aset Produktif jatuh tempo, bank tidak menerima pembayaran atas pokok dan/atau bunga dan/atau tagihan lainnya; atau

c. Debitur tidak dapat memenuhi persyaratan lain yang ditetapkan oleh bank (selain pembayaran pokok dan/atau bunga) dan dapat mengakibatkan terjadinya wanprestasi.

Sebelumnya pernah dilakukan penelitian terkait faktor-faktor yang mempengaruhi kredit bermasalah seperti pertama dari sisi pertumbuhan kredit, dilakukan oleh Anjom dan Karim (2016) pada negara yang tergabung dalam South Asian Association for Regional Cooperation (SAARC) dan Skarica (2014) pada negara yang tergabung dalam Central and Eastern Europe (CEE) yang memberikan hasil bahwa pertumbuhan kredit memberikan dampak positif terhadap NPL. Kemudian kedua dari jenis kredit yang disalurkan dimana porsi kredit produktif diuji pengaruhnya terhadap tingkat NPL pada Bank Pembangunan Daerah oleh Rokhim dan Yanti (2014) dengan hasil yang menunjukkan bahwa terdapat hubungan signifikan positif antara porsi kredit produktif terhadap tingkat NPL. Faktor yang ketiga adalah tingkat bunga pinjaman bank, dimana pada penelitian yang dilakukan oleh Messai dan Jouini (2013); Barus dan Erick (2016); Anjom dan Karim (2016) serta Soebagio (2005) menunjukan pengaruh positif antara bunga terhadap NPL. Dan faktor yang terakhir adalah inflasi, dimana pada penelitian yang dilakukan oleh Soebagio (2005) yang menunjukan hasil 
bahwa inflasi berpengaruh signifikan positif terhadap NPL, sedangkan pada peneliatian yang dilakukan oleh Firmanysah (2014) menunjukkan hasil yang sebaliknya. Sedangkan pada penelitian berikut, akan disajikan tahun penelitian yang terbaru yakni tahun 2013 sampai dengan tahun 2017 dan secara khusus pada penelitian berikut, analisa atas pengaruh jenis kredit terhadap kredit bermasalah akan dilakukan pada seluruh bank umum yang ada di Indonesia, tidak hanya pada Bank Pembangunan Daerah saja. Kerangka pemikiran pada penelitian ini akan digambarkan pada gambar 1 sebagai berikut:

Gambar 1. Kerangka Pemikiran

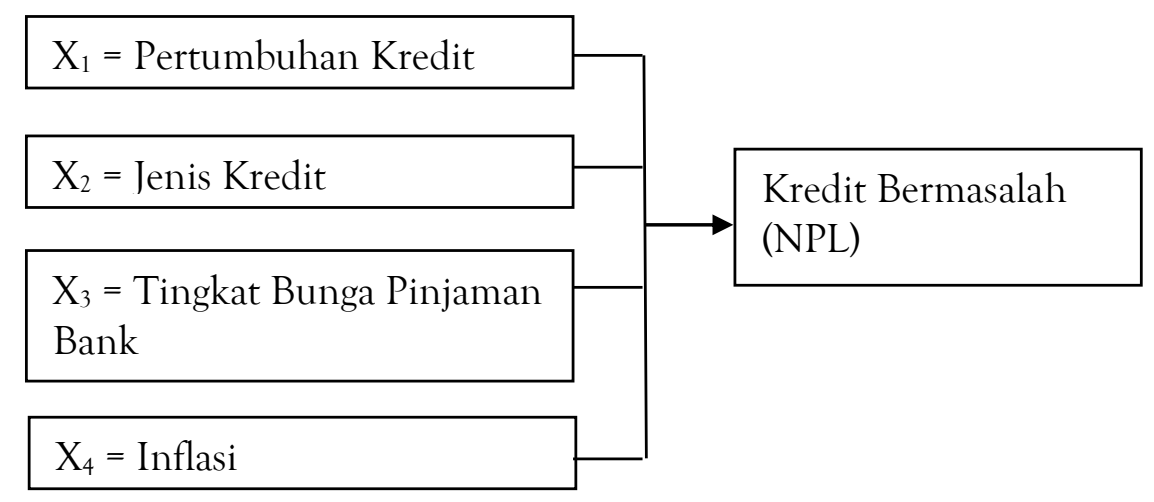

\subsection{Pengaruh Pertumbuhan Kredit terhadap Kredit Bermasalah}

Bank dalam menjalankan usahanya akan selalu diminta untuk terus tumbuh dan berkembang, terutama dari sisi kredit yang disalurkannya. Hal tersebut karena kredit akan menghasilkan bunga yang nantinya menjadi sumber pendapatan utama bagi bank. Karyawan bank selalu diberikan target agar kredit yang disalurkannya dapat selalu tumbuh dan memberikan kontribusi bagi bank. Namun demikian apabila pertumbuhan dari sisi kredit yang disalurkan tersebut terlalu agresif dan tidak terkontrol, dapat memberikan dampak negatif bagi bank itu sendiri. Sudut pandang akan pertumbuhan kredit yang terlalu cepat menyebabkan kredit bermasalah tidak dapat diabaikan begitu saja, namun juga tidak dapat langsung di terima tanpa adanya pertanyaan. Jika pertumbuhan kredit yang cepat terjadi karena bank ingin menyalurkan kredit dengan cara menurunkan standarnya, maka akan mendorong kredit bermasalah untuk meningkat. Namun apabila pertubuhan kredit yang tinggi terjadi karena adanya perubahan sudut pandang para pelaku bisnis dengan bisnis (usaha) yang menjanjikan dimana mereka lebih memilih meminjam kepada bank dibandingkan dengan mendapatkan dana tambahan dari pasar modal maka pertumbuhan pada kredit bermasalah tidak harus terjadi (Keeton, 1999). Pada tahun 2007 terjadi bencana keuangan di Amerika serikat berupa subprime mortgage yang berdampak pada munculnya tingkat kredit bermasalah yang tinggi sehingga bank-bank tersebut harus mencatatkan kredit bermasalah yang tinggi. Kejadian ini terjadi karena adanya pertumbuhan kredit yang sangat tinggi (credit boom) dan adanya penggelembungan pasar pada sektor perumahan (Pajarskas dan Jociene, 2014). Pada penelitian sebelumnya juga pernah dilakukan penelitian untuk melihat pengaruh atas 
pertumbuhan kredit terhadap NPL yang dilakukan oleh Anjom dan Karim (2016) dan Skarica (2014) yang memperoleh hasil bahwa pertumbuhan kredit memberikan dampak positif terhadap NPL. Berdasarkan penjelasan diatas dan hasil penelitian sebelumnya, maka dapat disimpulkan bahwa pertumbuhan kredit berpengaruh positif terhadap kredit bermasalah.

$H_{1}$ : Pertumbuhan kredit berpengaruh positif terhadap kredit bermasalah.

\subsection{Jenis Kredit terhadap Kredit Bermasalah}

Kredit dapat digolongkan menjadi sembilan golongan, yakni; berdasarkan jangka waktu, sifat penggunaan, keperluan, sifat penarikan, sifat pelunasan, valuta, mode pembiayaan, lokasi bank dan cara penarikan (Ikatan Bankir Indonesia dan Lembaga Sertifikasi Profesi Perbankan, 2013). Pada penelitian berikut, berdasarkan penggunaannya kredit dibagi menjadi dua jenis yakni; 1) kredit konsumtif dimana sumber pembayarannya umumnya berasal dari gaji atau pendapatan lainnya, bukan berasal dari objek yang dibiayainya dan 2) kredit komersial yang sumber pembayarannya berasal dari usaha yang dibiayainya (Ikatan Bankir Indonesia dan Lembaga Sertifikasi Profesi Perbankan, 2013). Dengan demikian, diduga bahwa semakin besar porsi pembiayaan kredit komersial maka akan semakin besar kredit bermasalahnya, karena pada kredit konsumtif kepastian pembayaran kepada bank lebih dapat terjaga dibandingkan dengan kredit komersial. Selain hal tersebut, sebelumnya juga telah dilakukan penelitian yang menguji pengaruh porsi kredit produktif terhadap tingkat NPL oleh Rokhim dan Yanti (2014) dengan hasil yang menunjukkan bahwa terdapat hubungan signifikan positif antara porsi kredit produktif terhadap tingkat NPL. Berdasarkan penjelasan diatas, dapat disimpulkan bahwa apabila perbankan memiliki porsi kredit komersial yang semakin besar, maka akan dapat menimbulkan kredit bermasalah yang semakin besar, sehingga jenis kredit berpengaruh terhadap kredit bermasalah.

$\mathrm{H}_{2}$ : Porsi Kredit Komersial berpengaruh positif terhadap kredit bermasalah.

\subsection{Tingkat Bunga Pinjaman Bank terhadap Kredit Bermasalah}

Tingkat bunga pinjaman bank atau yang biasa dikenal dengan Suku Bunga Dasar Kredit (SBDK) dan dalam bahasa Inggris adalah Prime Lending Rate merupakan suku bunga terendah yang digunakan sebagai dasar bagi Bank dalam penentuan suku bunga kredit yang dikenakan kepada nasabah Bank (SE No.15/1/DPNP, 2013). Perubahan pada suku bunga langsung dapat memberikan dampak terhadap kemampuan membayar dari peminjam dimana peningkatan pada suku bunga berarti semakin tinggi juga kewajiban yang harus dibayarkan oleh peminjam kepada bank (Messai dan Jouini, 2013). Sebelumnya pernah dilakukan penelitian yang meneliti pengaruh bunga terhadap NPL oleh Messai dan Jouini (2013); Barus dan Erick (2016); Anjom dan Karim (2016) serta Soebagio (2005) yang menunjukan pengaruh positif. Berdasarkan penjelasan diatas dan hasil penelitian sebelumnya, maka dapat disimpulkan bahwa tingkat bunga pinjaman bank berpengaruh positif terhadap rasio NPL.

$\mathrm{H}_{3}$ : Tingkat bunga pinjaman bank berpengaruh positif terhadap kredit bermasalah. 


\subsection{Pengaruh Inflasi terhadap Kredit Bermasalah}

Inflasi dapat didefinisikan sebagai meningkatnya harga secara umum dan berkelanjutan. Kenaikan harga yang berasal hanya dari satu atau dua barang saja tidak dapat disebut inflasi kecuali jika kenaikan tersebut meluas (atau mengakibatkan kenaikan harga) pada barang lainnya. Kebalikan dari inflasi disebut deflasi. Indikator yang umumnya digunakan untuk mengukur tingkat inflasi adalah Indeks Harga Konsumen (IHK). Perubahan IHK menunjukkan pergerakan harga dari sejumlah barang dan jasa yang dikonsumsi oleh masyarakat (bi.go.id, 2017). Inflasi yang semakin tinggi, dapat menurunkan kemampuan membayar peminjam sehingga mampu mendorong peningkatan pada kredit bermasalah (Beaton et all, 2016), namun demikian dengan meningkatnya harga kebutuhan masyarakat akan cenderung untuk tetap mengutamakan kepentingan kewajibannya dalam membayar/melunasi hutang pembiayaan (Firmansyah, 2014). Sebelumnya, pernah dilakukan penelitian yang meneliti hubungan antara inflasi terhadap NPL yang dilakukan oleh Soebagio (2005) yang menunjukan hasil bahwa inflasi berpengaruh signifikan positif terhadap NPL. Sedangkan pada peneliatian yang dilakukan oleh Firmanysah (2014) menunjukkan hasil yang sebaliknya, dimana masyarakat terbukti akan mengutamakan kepentingan kewajibannya dalam membayar/melunasi hutang pembiayaannya. Berdasarkan penjelasan diatas dan hasil penelitian sebelumnya, dengan demikian disimpulkan bahwa Inflasi berpengaruh positif terhadap rasio NPL.

$\mathrm{H}_{4}$ : Inflasi berpengaruh positif terhadap kredit bermasalah.

\section{METODE PENELITIAN}

Pada penelitian berikut, yang menjadi populasi adalah seluruh perbankan umum yang ada di Indonesia. Pada tahun 2017 di Indonesia jumlah perbankan umum tercatat sebanyak 115 bank (OJK.go.id, 2017). Pengambilan sample dilakukan dengan metode purposive sampling dengan tujuan agar sampel yang diambil dapat menyesuaikan dengan desain penelitian. Kriteria sampel pada penelitian ini adalah sebagai berikut; 1) Bank melakukan publikasi atas laporan keuangan audit tahun 2013 s.d. 2017 pada website resmi bank, 2) Bank merupakan bank umum konvensional dan 3) Kantor pusat berkedudukan di Indonesia.

Dari total sebanyak 115 bank umum yang tercatat pada tahun 2017, sebanyak 11 bank tidak dapat diakses laporan keuangannya melalui website resmi bank, 13 bank merupakan bank syariah, dan 9 bank kantor pusat berkedudukan di luar negeri. Analisis statistik pada penelitian berikut menggunakan analisa regresi linier berganda, dengan persamaan sebagai berikut:

\section{$\mathrm{NPL}=\alpha+\beta 1$.CRED.GROWTH $+\beta 2$.PORT.COMM $+\beta 3$. INTEREST + $\beta 4$.INFLATION $+\varepsilon$}

Dimana:

NPL $=$ Kredit bermasalah,

CRED.GROWTH = Pertumbuhan kredit,

PORT.COMM. = Porsi Kredit komersial, 
INTEREST $=$ Tingkat bunga pinjaman bank.

INFLATION = Tingkat inflasi, dan

$\varepsilon=$ error.

\section{HASIL DAN PEMBAHASAN}

Untuk melihat kelayakan data, uji asumsi klasik terlebih dahulu dilakukan sebelum melakukan analisa regresi linier berganda. Uji asumsi klasik terdiri empat tahap yakni; 1) uji normalitas, 2) uji multikolinieritas, 3) uji autokorelasi dan 4) uji heteroskedastisitas. Hasil pengolahan uji asumsi klasik tersebut disajikan dalam gambar 1, 2 dan tabel 1.

\section{Gambar 1. Uji Normalitas}

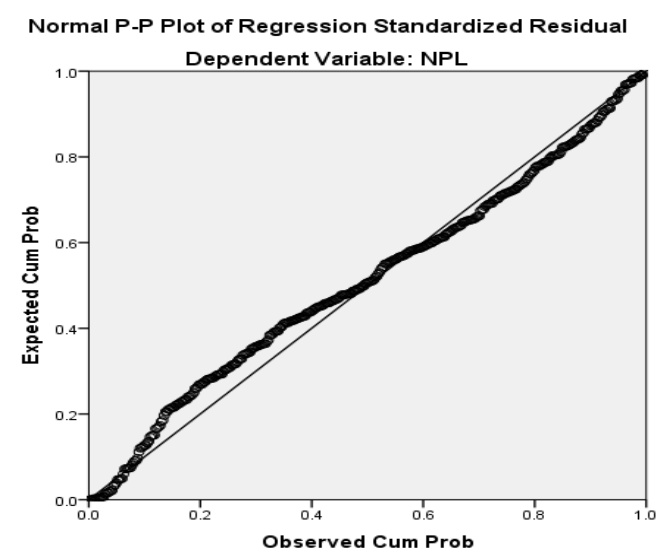

\section{Gambar 2. Uji Heteroskedastisitas}

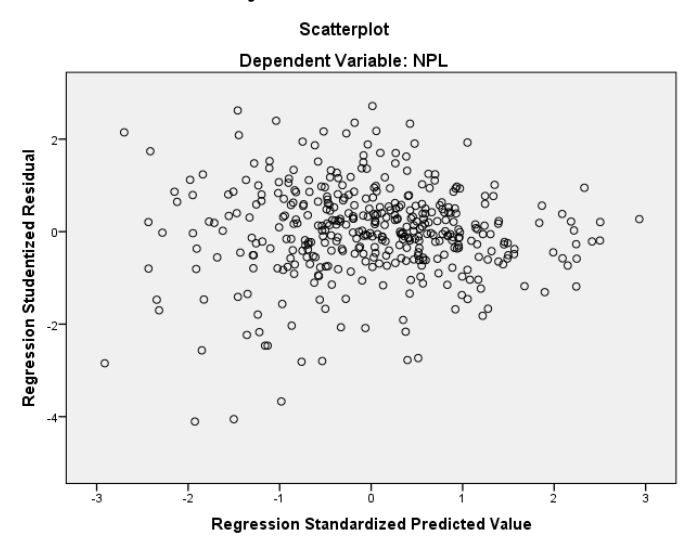

Sumber: Data diolah

Berdasarkan data yang diuji menggunakan grafik normal plot pada gambar 1 menunjukkan hasil yang normal, dapat dilihat bahwa sebaran data berada disekitar garis normal. Sementara pada hasil output uji heteroskedastisitas (gambar 2) teramati bahwa titik-titik tidak membentuk sebuah pola, dan menyebar di atas dan di bawah angka 0 pada sumbu Y, dengan demikian dapat disimpulkan bahwa dalam model regresi tidak terdapat masalah heteroskedastisitas.

Tabel 1. Uji Multikolinieritas dan Uji Autokorelasi

\begin{tabular}{|l|l|l|l|}
\hline \multirow{2}{*}{} & \multicolumn{2}{|c|}{ Uji Multikolinieritas } & \multirow{2}{*}{ Uji Autokorelasi } \\
\cline { 2 - 3 } & Tolerance & VIF & \multirow{2}{*}{ Durbin-Watson } \\
\hline Cred.Growth & .949 & 1.054 & \multirow{2}{*}{1.865} \\
\hline Port.Comm. & .992 & 1.008 & \multirow{2}{*}{1.865} \\
\hline Interest & .986 & 1.014 & \\
\hline Inflation & .944 & 1.059 & \multicolumn{2}{|c}{} \\
\hline
\end{tabular}

Sumber: Data diolah

Pengujian kualitas yang ketiga adalah uji multikolinieritas, dan pada tabel 1 teramati bahwa keempat variabel independen; cred.growth, port.comm, interest dan 
inflation memiliki nilai tolerance lebih dari 0,10 dan nilai VIF kurang dari 10. Berdasarkan data tersebut dapat diambil kesimpulan bahwa pada masing-masing variabel independen tidak terdapat gejala multikolinieritas. Pengujian kualitas yang terakhir adalah uji autokorelasi, berdasarkan tabel 1 diperoleh nilai Durbin Watson sebesar 1,865, sedangkan nilai DU yang diperoleh untuk n (jumlah data) 410 dan jumlah k sebanyak 4 adalah 1,85265, sehingga DU $<$ DW $(1,8526<1,865)$. Dengan demikian, dapat diambil kesimpulan bahwa tidak terjadi autokorelasi pada penelitian ini.

Setelah dilakukan uji asumsi klasik dan diperoleh kesimpulan bahwa kualitas data yang diperoleh merupakan data yang baik, maka selanjutnya dilakukan pengujian hipotesis dengan melakukan uji t dan uji koefisien determinasi.

Tabel 2. Uji t dan Koefisien Determinasi

\begin{tabular}{|c|c|c|c|c|}
\hline Variabel & Koefisien $B$ & $\mathbf{t}$ & Sig. & Adjusted R Square \\
\hline (Constant) & -1.028 & -1.864 & .063 & \multirow{5}{*}{.158} \\
\hline Cred.Growth & .170 & 5.055 & .000 & \\
\hline Port.Comm. & .460 & 2.952 & .003 & \\
\hline Interest & .797 & 3.716 & .000 & \\
\hline Inflation &. .322 & -4.025 & .000 & \\
\hline
\end{tabular}

Sumber: Data diolah

Adjusted $R$ square dari model regresi pada penelitian ini adalah sebesar 15,8\%, hal ini berarti model regresi dapat menjelaskan variabel dependen sebesar 15,8\% dan sisanya yaitu sebesar $84,2 \%$ dijelaskan oleh variabel lain yang tidak termasuk dalam penelitian ini.

Berdasarkan hasil uji $t$ yang telah dilakukan, diketahui bahwa variabel pertumbuhan kredit memiliki koefisien sebesar 0,170 dan berpengaruh positif signifikan dengan nilai signifikansi 0,000. Berdasarkan hasil tersebut, maka dapat disimpulkan bahwa $\mathrm{H}_{1}$ dapat diterima. Dengan demikian bisa diambil kesimpulan bahwa pertumbuhan kredit berpengaruh terhadap kredit bermasalah. Hasil penelitian membuktikan bahwa ketika bank melakukan pertumbuhan kredit yang tinggi dalam waktu yang cepat, bank cenderung menurunkan standar dalam memilih nasabahnya (Keeton, 1999), dan hasil tersebut sejalan dengan penelitian yang dilakukan oleh Anjom dan Karim (2016); Skarica (2014) serta Keeton (1999) terkait pengaruh pertumbuhan kredit terhadap kredit bermasalah.

Hasil penelitian juga menunjukkan bahwa jenis kredit memiliki pengaruh yang positif signifikan terhadap kredit bermasalah. Dengan nilai koefisien sebesar 0,460 dan nilai signifikansi 0,003. Berdasarkan hasil tersebut, maka dapat disimpulkan bahwa $\mathrm{H}_{2}$ dapat diterima. Dengan demikian bisa diambil kesimpulan bahwa porsi kredit komersial berpengaruh terhadap kredit bermasalah. Hasil pada penelitian tersebut membuktikan bahwa semakin besar porsi pembiayaan kredit komersial maka akan semakin besar kredit bermasalahnya, karena pada kredit konsumtif kepastian pembayaran kepada bank lebih dapat terjaga dibandingkan dengan kredit komersial. 
Dan hal ini sejalan dengan penelitian yang dilakukan oleh Rokhim dan Yanti (2014) dengan hasil yang menunjukkan bahwa terdapat hubungan signifikan positif antara porsi kredit produktif terhadap tingkat NPL.

Hasil penelitian ini menunjukkan bahwa interest memiliki pengaruh yang positif signifikan terhadap kredit bermasalah. Dengan koefisien sebesar 0,797. Berdasarkan hasil tersebut, menunjukkan bahwa $\mathrm{H}_{3}$ dapat diterima. Dengan demikian bisa diambil kesimpulan bahwa inflasi berpengaruh terhadap kredit bermasalah. Hal ini menunjukkan bahwa perubahan pada tingkat bunga pinjaman bank langsung dapat memberikan dampak terhadap kemampuan membayar dari peminjam dimana peningkatan pada suku bunga berarti semakin tinggi juga kewajiban yang harus dibayarkan oleh peminjam kepada bank. Hasil penelitian berikut sejalan dengan penelitian yang dilakukan oleh Messai dan Jouini (2013); Barus dan Erick (2016); Anjom dan Karim (2014) serta Soebagio (2005) yang menunjukan pengaruh positif antara interest terhadap kredit bermasalah.

Berdasarkan hasil pengujian yang telah dilakukan juga diketahui bahwa variabel inflasi memiliki koefisien sebesar -0,322 dan berpengaruh negatif signifikan dengan nilai signifikansi 0,000 . Berdasarkan hasil penelitian yang telah dilakukan tersebut maka bisa disimpulkan bahwa $\mathrm{H}_{4}$ ditolak. Dengan demikian dapat diambil kesimpulan bahwa inflasi berpengaruh negatif terhadap kredit bermasalah. Tentunya penolakan atas hipotesis berikut memiliki alasan, dimana pada kurun waktu tahun 2013 hingga 2017 di Indonesia tidak terdapat pertumbuhan inflasi yang tinggi (masih dibawah 8,38\%) sehingga masyarakat masih mampu untuk memenuhi kewajibannya. Sebelumnya juga pernah terdapat penelitian yang menunjukkan pengaruh negatif atas inflasi terhadap kredit bermasalah yang dilakukan oleh Firmansyah (2014) dan Nurismalatri (2017) yang dapat kemudian disimpulkan bahwa meskipun terdapat inflasi dengan pertumbuhan yang wajar, bank tidak perlu khawatir dalam menyalurkan kreditnya karena masyarakat Indonesia masih mengutamakan kepentingan kewajiban dalam membayar/melunasi hutang pembiayaannya.

\section{PENUTUP}

Berdasarkan penelitian yang telah dilakukan, dengan meneliti sebanyak 82 bank umum yang terdapat di indonesia untuk periode penelitian selama lima tahun, dapat disimpulkan bahwa masing-masing variabel pertumbuhan kredit, jenis kredit dan tingkat bunga pinjaman bank memberikan pengaruh positif terhadap kredit bermasalah, sedangkan inflasi berpengaruh negatif terhadap kredit bermasalah. Hasil penelitian ini sejalan dengan penelitian yang sebelumnya telah dilakukan oleh Anjom dan Karim (2014), Keeton (1999), Rokhim dan Yanti (2014), Messai dan Jouini (2013), Barus dan Erick (2016) serta Firmansyah (2014).

Hasil dari penelitian ini dapat menjadi masukan bagi para pelaku perbankan untuk lebih memperhatikan faktor-faktor seperti pertumbuhan kredit, jenis kredit, tingkat bunga pinjaman bank dan inflasi dalam menyalurkan kreditnya, dimana pada penelitian berikut keempat faktor tersebut terbukti memberikan dampak yang signifikan terhadap kredit bermasalah. 
Saran bagi peneliti selanjutnya dapat melihat dari sisi lain sebagai variabel independen seperti dengan melihat dari sisi faktor internal bank yakni; ukuran bank, jumlah loan officer pada bank, kualitas sumber daya manusia dan pelayanan, serta dapat juga menambahkan dari sisi faktor eksternal bank seperti kurs, dan lain-lain untuk melihat pengaruhnya terhadap kredit bermasalah atau dapat meneliti ukuran tingkat pertumbuhan kredit yang sehat. Hal tersebut dapat dilakukan karena pada penelitian ini variabel pertumbuhan kredit, jenis kredit, tingkat bunga pinjaman bank, dan inflasi hanya mampu mendeskripsikan sebesar 15,8\% dari kredit bermasalah dan tidak mengukur tingkat pertumbuhan kredit yang sehat.

\section{DAFTAR PUSTAKA}

Anjom, W. \& Karim, A. M. (2016). Relationship Between Non-Performing Loans And Macroeconomic Factors With Bank Specific Factors: A Case Study On Loan Portfolios - SAARC Countries Perspective. ELK Asia Pacific Journal Of Finance And Risk Management. 7(2)

Bank Indonesia. (2012). Peraturan Bank Indonesia NOMOR 14/ 15 /PBI/2012 Tentang Penilaian Kualitas Aset Bank Umum . (2013). Surat Edaran NOMOR 15/1/DPNP tahun 2011 Tentang

Transparansi Informasi Suku Bunga Dasar Kredit . (2016). Laporan Perekonomian Indonesia tahun 2016 (2017). Definisi Inflasi. Diakses dari

https://www.bi.go.id/id/moneter/inflasi/pengenalan/Contents/Default.aspx

Barus, A. C. \& Erick. (2016). Analisis Faktor-faktor yang Mempengaruhi Non Performing Loan Pada Bank Umum di Indonesia. Jurnal Wira Ekonomi Mikroskil. 6(2)

Beaton, K., Myrvoda, A. \& Thompson, S. (2016). Non-Performing Loans in the ECCU: Determinants and Macroeconomic Impact. International Monetary Fund Working Paper

Firmansyah, I. (2014). Determinant of Non Performing Loan: The Case of Islamic Bank in Indonesia. Bulletin Ekonomi Moneter dan Perbankan. 17(2): 242-254

Gumanti, T. A. (2009). Teori Sinyal dalam Manajemen Keuangan. Usahawan. 06 Ikatan Bankir Indonesia \& Lembaga Sertifikasi Profesi Perbankan. 2013. Memahami Bisnis Bank. Edisi ke - 1. Jakarta Pusat : Penerbit PT Gramedia Pustaka Utama

Keeton, W. R. (1999). Does Faster Loan Growth Lead to Higher Loan Losses? Economic Review Federal Reserve Bank of Kansas City

Maryandi, M. S., Yaya. R., \& Supriyono. E. (2015). Analisis Pengaruh Faktor Internal Bank Terhadap NPL dan Aplikasi Loan Loss Ratio-Based Model. Jurnal Bisnis Teori dan Implementasi. 6(2).

Messai, A. S. \& Jouini, F. (2013). Micro and Macro Determinants of Non-Performing Loans. International Journal of Economics and Financial issues. 3(4): 852-860

Nurismalatri. (2017). Analisis Pengaruh Makro Ekonomi Terhadap Kredit Bermasalah Perbankan Indonesia. Jurnal Sekuritas. 1(2): 103-116 
Otoritas Jasa Keuangan. (2017). Daftar Alamat Kantor Pusat Bank Umum Dan Syariah. Diakses dari https://www.ojk.go.id/id/kanal/perbankan/data-danstatistik/Pages/Daftar-Alamat-Kantor-Pusat-Bank-Umum-Dan-Syariah.aspx.

Pajarskas, V. \& Jociene, A. (2014). Subprime Mortgage Crisis in The United States in 2007-2008: Causess and Consuquences (Part I). Ekonomika. 93(4): 85-118

Republik Indonesia. (1998). Undang-Undang Republik Indonesia No. 7 Tahun 1992 Revisi 1998

Rokhim, R. \& Yanti, M. I. S. M. (2014). Resiko NPL Kredit Bank Pembangunan Daerah Sebagai Regional Champion. Jurnal Keuangan dan Perbankan. 18(1): 120 129

Rose, P. S. \& Hudgins, S. C. (2010). Bank Management Eु Financial Services (8th ed.). New York : McGraw-Hill

Sakina RDS. 2017. Rasio Kredit Bermasalah Naik, Ini Penjelasan Bank Mandiri. Diakses dari https://ekonomi.kompas.com/read/2017/02/14/202444926/rasio.kredit.ber masalah.naik.ini.penjelasan.bank.mandiri

Sharpe, S. A. (1990). Asymmetric Information, Bank Lending and Implicit Contracts: A Stylized Model of Customer Relationships. The Journal of Finance. 45(4): 1069. 1087

Skarica, B. (2014). Determinants of Non-Performing Loans in Central and Eastern European Countries. Financial Theory and Practice. 38(1): 37-59

Soebagio, H. (2005). Analisis Faktor-faktor yang Mempengaruhi Terjadinya Non Performing Loan Pada Bank Umum Komersial (Studi Empiris pada Sektor Perbankan di Indonesia). Thesis. Semarang: Universitas Diponegoro

Suheriadi. 2017. BTN Bidik NPL Dibawah 3\%. Diakses dari http://infobanknews.com/btn-bidik-npl-dibawah-31/

World Bank. (2017). Bank Nonperforming Loans to total gross loans. Diakses dari https://data.worldbank.org/indicator/FB.AST.NPER.ZS 